\title{
ISO/TR 12300:2016 for clinical cross-terminology mapping: contribution to nursing
}

\author{
ISO/TR 12300:2016 para mapeamento entre terminologias \\ clínicas: contribuição para a enfermagem \\ ISO/TR 12300:2016 para mapeo entre terminologías clínicas: \\ aporte para la enfermería
}

How to cite this article:

Torres FBG, Gomes DC, Ronnau L, Moro CMC, Cubas MR. ISO/TR 12300:2016 for clinical cross-terminology mapping: contribution to nursing. Rev Esc Enferm USP. 2020;54:e03569. doi: https://doi.org/10.1590/S1980-220X2018052203569

\section{Fernanda Broering Gomes Torres ${ }^{1}$ \\ Denilsen Carvalho Gomes ${ }^{1}$ \\ Lucas Ronnau ${ }^{1}$ \\ Cláudia Maria Cabral Moro ${ }^{1}$ \\ Marcia Regina Cubas ${ }^{1}$}

${ }^{1}$ Pontifícia Universidade Católica do

Paraná, Programa de Pós-Graduação em

Tecnologia em Saúde, Curitiba, PR, Brazil.

\begin{abstract}
This theoretical and reflective study aimed to assess the contribution of the ISO/TR 12300:2016 document for the mapping of nursing terminology. The referred document and related articles were used as an empirical framework. The study analyzed the content of the document, highlighting cardinality and equivalence principles. The standard presents conceptual and operational basis for mapping, with cardinality and equivalence as the support for the categorization of cross-terminology mapping in the area of nursing. Cardinality verifies candidate target terms to represent the source term, while the equivalence degree scale checks semantic correspondence. Among the principles included in the ISO/TR 12300:2016, cardinality and equivalence contribute to the accurate representation of the results of the cross-terminology mapping process and its use should decrease inconsistencies.
\end{abstract}

\section{DESCRIPTORS}

Standardized Nursing Terminology; Vocabulary, Controlled; Health Information Interoperability.
Corresponding author:

Marcia Regina Cubas

Rua Imaculada Conceição, 1155 - Prado Velho CEP 80215-901 - Curitiba, PR, Brazil

m.cubas@pucpr.br 


\section{INTRODUCTION}

The process of cross-terminology mapping evaluates the relationship and equivalence between terms from different terminological systems $\mathrm{s}^{(1-3)}$. The reasons for its use include the promotion of interoperability ${ }^{(4)}$ data reuse ${ }^{(5)}$, identification of gaps in terminology ${ }^{(6)}$ and update of terminology versions ${ }^{(7)}$.

In health, there are examples of cross-terminology mapping between the Human Phenotype Ontology (HPO) and the Systematized Nomenclature of Medicine Clinical Terms (SNOMED-CT) ${ }^{(8)}$ and between the International Statistical Classification of Diseases and Related Health Problems (ICD-11) the International Classification of Health Interventions (ICHI) and the SNOMED-CT ${ }^{(9)}$. It is also applied to relate terms registered by health professionals and standardized languages, such as in the mapping of terms used in the care of the patient with asthma and the Logical Observation Identifiers Names and Codes $(\mathrm{LOINC})^{(10)}$.

In nursing, cross-terminology mapping is used in methodological proposals for the elaboration of terminology subsets of the International Classification for Nursing Practice $\left(\mathrm{ICNP}^{\circledast}\right)^{(11)}$, but is not limited to this classification, as it can be identified in the mapping between the SNOMED-CT subset and the North American Nursing Diagnosis Association International (NANDA-I), the Omaha Community Health System and the International Classification of Functioning, Disability and Health (ICF) ${ }^{(12)}$.

It is also used for mapping terms registered by nursing staff and terminology systems, as verified in the relationship between ICNP ${ }^{\infty}$ terms and terms registered in nursing evolution in a university hospital ${ }^{(13)}$ and extracted from interviews with the nursing staff of an intensive care unit ${ }^{(14)}$.

Different ways of categorizing cross-terminology mapping results were observed in studies in the area of nursing, among them: identical, similar, present in the definition of another term and new terms ${ }^{(13)}$; perfect mapping, more broad, less broad and unmapped ${ }^{(15)}$; positive, negative and hierarchical connections ${ }^{(16)}$; and exact, broader or narrower match $^{(17)}$. These differences may cause ambiguity in interpretation and undermine comparisons between studies.

International organizations that form a specialized system for drafting and adopting standards in health informatics have developed the International Organization for Standardization/Technical Report (ISO/TR) 12300:2014 standard to subsidize cross-terminology mapping among terminology. In Brazil, the Special Studies Commission (CEE/078) of the Brazilian Association of Technical Standards (ABNT) elaborated the translation of the document, called ISO/TR 12300:2016 ${ }^{(2)}$, which proposes principles for quality mapping, contributing to a decreased clinical risk by sharing terms in different terminological structures ${ }^{(2)}$.

Considering the recent publication of this document and the relevance of its application to minimize the limitations of the categorization of mapping results, this article aims to reflect on its contribution to terminology mapping in nursing.

\section{METHOD}

Theoretical and reflective study, using ISO/TR 12300:2016 and studies that performed cross-terminology mapping as empirical framework and support for the discussion about nursing contributions.

The material was analyzed and discussed by an interdisciplinary team, which allowed understanding the main points of the document and selecting two principles - cardinality and equivalence - to be the basis of the reflection proposed in this article. This choice is justified as it contributes to minimize the different categorizations found in mapping studies in nursing. It is worth noting that for the development of cross-terminology mapping based on the document, its full consultation is recommended.

\section{ISO/TR 12300:2016 TECHNICAL DOCUMENT}

The ISO/TR 12300:2016 is divided in seven chapters. The first three addresses general issues: scope, terms and definitions for mapping; and the abbreviations and symbols used in the document ${ }^{(2)}$. The chapter terms and definitions present the standardization of the concepts of source mapping and target mapping. The first refers to the source document, containing the source term, and the second, to the document that will be compared to the source document, that contains the target term. Using this standardization reduces misinterpretation of studies by clarifying which document is the target of the comparison.

The fourth chapter highlights the decision-making matrix used to establish quality indicators, costs and clinical risks involved. For example, mapping with more than one purpose is more costly to develop and to maintain, thus, the matrix offers a "low to medium" quality indicator and a "high" clinical risk ${ }^{(2)}$. The matrix is important for feasibility and governance analysis, helping in the elaboration of feasible schedules and budgets.

The fifth chapter describes the applications of mapping, which include health statistics, groupings of clinical diagnostic codes for financing purposes and the development of terminology subsets ${ }^{(2)}$

The sixth chapter presents 21 principles for conducting and maintaining quality mapping ${ }^{(2)}$. In general, they are based on: clarification of the purpose of the mapping; setting; and form ${ }^{(2)}$.

By establishing principles for mapping, the document also directs the results, as the way they are presented is associated with their purpose; that is, the results of a terminology update are organized in a different form from the results of a study aimed at interoperability. The first would organize results in order to point out correspondences and gaps between terms, like the study that showed the lack of coverage in relation to allergic diseases in CID-11(7). The second organizes the results to establish whether or not it is possible to share data between different structures, like the study that verified the equivalence of a drug classification system for SNOMED-CT ${ }^{(4)}$.

The setting guides the definition of fundamental aspects of mapping: what will the mapping be used for? What steps 
will be followed? How will the mapping be maintained? Will the mapping be manual, automated or both?(2) The importance of documenting these issues is highlighted.

In terms of form, the document indicates the need of formal computational representation, so that the mapping is computer readable and allows computational processing and machine translation ${ }^{(2)}$. In addition to facilitating the cross-terminology mapping process, computational representation reduce manual mapping errors and the time spent by researchers ${ }^{(18)}$.

Other contributions of the standard are based on quality assurance, including consensus and validation of results among the team, and maintenance and continuous improvement of mapping through update based on usability fee$\mathrm{dback}^{(2)}$. Among the techniques used to validate a mapping is reverse mapping, which maps terms from the target document to the source document to detect possible errors ${ }^{(2)}$.

The last chapter reinforces questions about the mapping development and maintenance team ${ }^{(2)}$. Since mapping processes involve a group, role assignment organizes the necessary tasks. The team involved must consist of the following members: (i) sponsor, responsible for ordering the mapping, which may be a government agency, an institution or a health organization; (ii) mapping manager, responsible for the project's management, personnel and other resources; (iii) expert team leader, responsible for overseeing the technical aspects, providing staff with expert knowledge and support; (iv) a mapping expert, who must have knowledge of the terminological resources (source and target) and is responsible for developing and revising mapping in order to guarantee its reproducibility; (v) clinical support, responsible for providing up-to-date knowledge of clinical practice; (vi) consensus management expert, responsible for final consensus decisions, when the expert team leader and the mapping expert do not agree; (vii) information technology support, responsible for developing or managing computational resources that support the development and maintenance of mapping ${ }^{(2)}$.

\section{CONTRIBUTION TO NURSING}

The principle of cardinality assists the researcher when deciding between one or more candidate target document terms to represent one or more source document terms. They can find "one to one", "one to many", "many to one" and "many to many" correspondence (Chart 1).

In a mapping between terms of the Architecture, Terminology, Interface and Knowledge (ATIC) and of the NANDA-I, cardinality of "one to many" was found in the term "anxiety" for "anxiety" and "separation anxiety", while "many to one" was found in the terms "functional urinary incontinence" and "emergency urinary incontinence" for the term "urinary incontinence"(16).

Equivalence between terms can be observed through cardinality; however, "one to one" does not always express semantic equivalence ${ }^{(2)}$, because the domain area and cultural context of the mapped term must be considered. In countries that share the same language, such as Brazil and Portugal, the term "penso" may have "one to one" cardinality; however, if mapped by Portuguese researchers, the term refers to bandages and is related to the dressing of wounds and, if mapped by Brazilian researchers, it is associated with the verb "to think" and is related to reflection and combination of ideas. These questions highlight that cross-cultural adaptation must be considered in the process of terminology mapping, since history and cultural roots may result in different ways of understanding the terms ${ }^{(19)}$. Thus, it is very likely that machine processing will not replace human analysis in this regard.

Chart 1 - Example of cardinality between source document and target document terms - Curitiba, PR, Brazil, 2018.

\begin{tabular}{|c|c|c|}
\hline Cardinality & $\begin{array}{c}\text { Source document } \\
\text { terms }\end{array}$ & $\begin{array}{c}\text { Target document } \\
\text { terms }\end{array}$ \\
\hline One to zero $(1: 0)$ & Obnubilation & - \\
\hline One to one $(1: 1)$ & Anxiety & Anxiety \\
\hline One to many $(1: *)$ & Pain & $\begin{array}{c}\text { Pain, abdominal } \\
\text { Pain, acute } \\
\text { Pain, absent } \\
\text { Pain, chronic }\end{array}$ \\
\hline Many to one $(*: 1)$ & $\begin{array}{c}\text { Choking risk } \\
\text { Aspiration risk } \\
\text { Low self-esteem risk } \\
\text { Apnea risk }\end{array}$ & Risk \\
\hline Many to many $(*: *)$ & $\begin{array}{c}\text { Change } \\
\text { Changed } \\
\text { Shift }\end{array}$ & $\begin{array}{c}\text { Change } \\
\text { Shift }\end{array}$ \\
\cline { 2 - 3 } & $\begin{array}{c}\text { Hydration } \\
\text { Liquid regime }\end{array}$ & $\begin{array}{c}\text { Liquid regime (or } \\
\text { hydration) } \\
\text { Liquid therapy (or } \\
\text { hydration) }\end{array}$ \\
\hline
\end{tabular}

"One to zero" cardinality may generate reflection on the lack of representation of the target terminology in a given domain area. In turn, "one to many" or "many to one" may indicate the breadth of a term, pointing to a hierarchical relationship of classes and subclasses when using a terminology such as ICNP ${ }^{\oplus}$. This can be seen in the register of broad or specific phenomena of nurses' practice, as in the register of the nursing diagnosis "pain" - representing a broad phenomenon - and the nursing diagnoses "labor pain", "ischemic pain", "wound pain" and "musculoskeletal pain"(20) - representing more specific phenomena.

Regardless of the cardinality obtained in the mapping process, the researcher's intervention is necessary because, when selecting the corresponding term, it is possible to observe loss or gain of meaning, which will be of greater or lesser importance according to the purpose of the mapping ${ }^{(2)}$.

This problem is also related to the equivalence principle, which assists the researcher in semantic analysis ${ }^{(2)}$. When there is not a minimum semantic correspondence between the term of the mapped documents, there is a gap in terminology coverage ${ }^{(17,21)}$. On the other hand, the expressive correspondence between terms may indicate the representation of the professional practices in terminology systems.

The degree of correspondence is assessed by categorizing the mapped terms. In studies prior to the document ISO/TR 12300/2016, different categories were identified to establish correspondence ${ }^{(13,17,22)}$. This standard allows a uniformity of categorization through an evaluation scale 
(Table 2), which describes the degree of equivalence between the mapped terms.

Chart 2 - Equivalence degree scale in the cross-terminology mapping according to ISO/TR 12300:2016 - Curitiba, PR, Brazil, 2018.

\begin{tabular}{|c|c|c|}
\hline Evaluation & Meaning & Examples \\
\hline 1 & $\begin{array}{c}\text { Equivalence of meaning: } \\
\text { lexical and conceptual. }\end{array}$ & $\begin{array}{c}\text { Asthma and asthma; } \\
\text { ovarian cyst and cyst in the } \\
\text { ovary. }\end{array}$ \\
\hline 2 & $\begin{array}{c}\text { Equivalence of meaning, } \\
\text { but with synonym. }\end{array}$ & $\begin{array}{c}\text { Urethral calculi and } \\
\text { urethral stones; gallstones } \\
\text { and cholelithiasis. }\end{array}$ \\
\hline 3 & $\begin{array}{c}\text { The source term is broader } \\
\text { and has less specific } \\
\text { meaning than the target } \\
\text { term. }\end{array}$ & $\begin{array}{c}\text { Obesity and morbid } \\
\text { obesity; diabetes and type II } \\
\text { diabetes mellitus. }\end{array}$ \\
\hline 4 & $\begin{array}{c}\text { The source term is narrower } \\
\text { and has more specific } \\
\text { meaning than the target } \\
\text { term. }\end{array}$ & $\begin{array}{c}\text { Feels ugly and self-image } \\
\text { problems; acute renal } \\
\text { failure syndrome due to } \\
\text { dehydration and acute renal } \\
\text { failure. }\end{array}$ \\
\hline 5 & $\begin{array}{c}\text { No mapping is possible. A } \\
\text { concept with some degree } \\
\text { of equivalence was not } \\
\text { found on the target (as } \\
\text { measured by any of the } \\
\text { other four evaluations) }\end{array}$ & \\
\hline
\end{tabular}

Source: Adapted from ABNT, $2016^{(2)}$.

The equivalence degree scale was used in a study conducted in Germany, which mapped terms from the records of an emergency department to SNOMED-CT and obtained $66 \%$ meaning equivalence ${ }^{(23)}$. The results obtained using the equivalence degree evaluation scale contribute to support reviews and updates of terminology systems ${ }^{(24)}$ and to improve the representation of professional practices in standardized languages, considering the constant reviews and updates of nursing terminologies.

The use of the ISO/TR 12300:2016 degree of equivalence scale can reduce clinical risk when mapped terms are used directly in-patient care. In this sense, the term "washing", defined in the $\mathrm{ICNP}^{\otimes}$ as "making something clean with water or other liquid and a cleaning agent"(20), can be understood, in care practice, as filling an infusion device, i.e. "washing equipment". Situations like this can lead to misinterpretations and wrong actions.

When the purpose of mapping is to measure the activities performed by the nursing staff, the scale can improve the accuracy of the results, anchoring the comparison between existing nursing activities with standardized terminologies. This can support the development of instruments that measure the time spent on care activities, which may contribute to nursing staff-sizing ${ }^{(25)}$.

Mapping between records of daily nursing practice and standardized languages contributes to the dialogue between different specialties and different countries ${ }^{(25)}$. The use of the document, especially the cardinality principle and the degree of equivalence scale can enhance this exchange of knowledge in different scenarios of the profession, while also supporting the translation of terminology resources. In addition, it fosters the categorization of mapping results, avoiding repeated work of users, given that it is possible to ascertain the equivalence relations considered by the developers.

The complexity of the cross-terminology mapping process requires attention, ability and time. To optimize the resources involved, health informatics can support this process $^{(18)}$ through self-organizing mapping ${ }^{(2)}$, so named when computational tools are used. This enables matching terms through established rules ${ }^{(2)}$, providing direct identification of the possible candidate term or terms to be evaluated and validated by the researcher ${ }^{(2,26)}$. Its performance may be enhanced by the use of computational rules based on cardinality and equivalence, as proposed by the ISO/ TR 12300:2016.

Among the efforts to automate the mapping process, there is the use of the Regenstrief LOINC ${ }^{\oplus}$ Mapping Assistant $\left(\mathrm{RELMA}^{\oplus}\right)^{(27)}$; of the Unified Medical Language System (UMLS) structure, to compare terms between different terminologies ${ }^{(28)}$; and of the Metamap, an algorithm that identifies and maps UMLS terms in free text in English ${ }^{(29)}$.

Despite of computer support, expert intervention is still needed. This was observed in the mapping between ICNP ${ }^{\circledast}$ terms for SNOMED-CT, via UMLS, in which the cardinality of "one to many" was observed in the term "interrupted breastfeeding", matched for the terms "inability to breastfeed" and "difficulty breastfeeding"; however, in the semantic evaluation of the experts, only the term "inability to breastfeed" was confirmed ${ }^{(30)}$.

Automation of the mapping process can reduce the effort and time spent by researchers ${ }^{(30)}$, enabling them to concentrate their efforts on the analysis and validation of the results obtained.

\section{FINAL CONSIDERATIONS}

The ISO/TR 12300:2016 document contributes to the accuracy of cross-terminology mapping. The principle of cardinality can support the decision between one or more terms, while the equivalence principle collaborates to standardize the categorization of results. This reduces possible inconsistencies, enhances communication between researches and facilitates comparison between different studies. These contributions can support reviews and updates of nursing terminology, contributing to the implementation of a standardized language and, consequently, improving records and communication between professionals and resulting in patient safety.

The limitation of this study is related to the fact that the standardization document is an international technical report that is not specific to mapping of nursing terms. Thus, one highlights the importance of future mapping studies based on the ISO/TR 12300:2016. This reflection contributed to the diffusion and application of the document in mapping in the nursing area.

\section{RESUMO}

Este estudo teórico-reflexivo teve como objetivo refletir sobre a contribuição da norma ISO/TR 12300:2016 para mapeamento de terminologias na área de enfermagem. Foram utilizados como base empírica a referida norma e artigos relacionados, analisando o conteúdo da norma e destacando os princípios de cardinalidade e equivalência. A norma apresenta bases conceituais e operacionais para o mapeamento, com a cardinalidade e a equivalência, ancorando a categorização dos resultados dos mapeamentos entre terminologias 
na área de enfermagem. A cardinalidade verifica os termos-alvo candidatos para representar o termo-fonte, enquanto a escala de grau de equivalência verifica a correspondência semântica. Entre os princípios inclusos na ISO/TR 12300:2016, a cardinalidade e a equivalência contribuem para a representação precisa dos resultados do processo de mapeamento cruzado e seu uso deve diminuir inconsistências.

\section{DESCRITORES}

Terminologia Padronizada em Enfermagem; Vocabulário Controlado; Interoperabilidade da Informação em Saúde.

\section{RESUMEN}

Este estudio teórico reflexivo tiene como fin reflexionar acerca del aporte de la norma ISO/TR 12300:2016 para el mapeo de terminologías en el área de enfermería. Fueron utilizados como base empírica la mencionada norma y artículos relacionados, analizando el contenido de la norma y destacando los principios de cardinalidad y equivalencia. La norma presenta bases conceptuales y operativas para el mapeo, con la cardinalidad y la equivalencia, anclando la categorización de los resultados de los mapeos entre terminologías en el área de enfermería. La cardinalidad verifica los términos meta candidatos para representar el término fuente, mientras que la escala de grado de equivalencia verifica la correspondencia semántica. Entre los principios incluidos en la ISO/TR 12300:2016, la cardinalidad y la equivalencia contribuyen a la representación precisa de los resultados del proceso de mapeo cruzado y su empleo debe de reducir inconsistencias.

\section{DESCRIPTORES}

Terminología Normalizada de Enfermería; Vocabulario Controlado; Interoperabilidad de la Información en Salud.

\section{REFERENCES}

1. Tannure MC, Salgado PO, Chianca TCM. Mapeamento cruzado: títulos diagnósticos formulados segundo a CIPE $®$ versus diagnósticos da NANDA Internacional. Rev Bras Enferm [Internet]. 2014 [citado 2018 jul. 20];67(6):972-8. Disponível em: http://www.scielo.br/pdf/ reben/v67n6/0034-7167-reben-67-06-0972.pdf

2. Associação Brasileira de Normas Técnicas. ISO/TR 12.300: Informática em saúde - princípios de mapeamento entre sistemas terminológicos. Rio de Janeiro; ABNT; 2016.

3. Gipson DS, Kirkendall ES, Gumbs-Petty B, Quinn T, Steen A, Hicks A, et al. Development of a pediatric adverse events terminology Pediatrics [Internet]. 2017 [cited 2018 June 20];139(1):e20160985. Available from: https://www.ncbi.nlm.nih.gov/pmc/articles/ PMC5292241/

4. Nelson SD, Parker J, Lario R, Winnenburg R, Erlbaum M, Lincoln MJ, et al. Interoperability of medication Classification Systems: lessons learned mapping Established Pharmacologic Classes (EPCs) to SNOMED. Stud Health Technol Inform [Internet]. 2017 [cited 2018 June 20];245:920-4. Available from: https://www.ncbi.nlm.nih.gov/pmc/articles/PMC5881380/

5. Kamdar MR, Tudorache T, Musen MA. A systematic analysis of term reuse and term overlap across biomedical ontologies. Semant Web [Internet]. 2009 [cited 2018 June 15];8(6):853-71. Available from: https://www.ncbi.nlm.nih.gov/pmc/articles/PMC5555235/

6. Ivory $\mathrm{CH}$. Mapping perinatal nursing process measurement concepts tostandardized terminologies. Comput Inform Nurs [Internet]. 2016 [cited 2018 July 20];34(7):312-20. Available from: https://www.ncbi.nlm.nih.gov/pmc/articles/PMC4938764/

7. Tanno LK, Calderon M, Papadopoulos NG, Demoly P. Mapping hypersensitivity/allergic diseases in the International Classification of Diseases (ICD)-11: cross-linking terms and unmet needs. Clin Transl Allergy [Internet]. 2015 [cited 2018 July 15];5:20. Available from: https://www.ncbi.nlm.nih.gov/pmc/articles/PMC4482039/

8. Dhombres F, Bodenreider O. Interoperability between phenotypes in research and healthcare terminologies-investigating partial mappings between HPO and SNOMED CT. J Biomed Semantics [Internet]. 2016 [cited 2018 June 20];7:3. Available from: https://www.ncbi.nlm. nih.gov/pmc/articles/PMC4748471/

9. Thun S, Dewenter H. ICD-11, ICHI and SNOMED CT-What do the standards mean for eHealth applications? BundesgesundheitsblattGesund. 2018;61(7):812-20. DOI: 10.1007/s00103-018-2759-2

10. Lougheed MD, Thomas NJ, Wsilewski NV, Morra AH, Minard JP. Use of SNOMED CT® and LOINC® to standardize terminology for primary care asthma electronic health records. J Asthma. 2018;55(6):629-39. DOI: 10.1080/02770903.2017.1362424

11. Carvalho CMG, Cubas MR, Nóbrega MML. Brazilian method for the development terminological subsets of ICNP®: limits and potentialities Rev Bras Enferm. 2017;70(2):430-5. DOI: http://dx.doi.org/10.1590/0034-7167-2016-0308

12. Kieft RAMM, Vreeke EM, Groot EM, Graaf-Waar HI, Van Gool CH, Koster N, et al. Mapping the Dutch SNOMED CT subset to Omaha System, NANDA International and International Classification of Functioning, Disability and Health. Int J Med Inform. 2018;111:77-82. DOI: 10.1016/j.ijmedinf.2017.12.025

13. Cubas MR, Pleis LE, Gomes DC, Costa ECR, Peluci APVD, Shmeil MAH, et al. Mapeamento e definição de termos registados por enfermeiros de um hospital especializado em emergência e trauma. Rev Enf Ref. 2017;4(12):45-54. DOI: http://dx.doi.org/10.12707/ RIV16067

14. Silva RS, Nóbrega MML, Medeiros ACT, Jesus NVA, Pereira A. Terms of the ICNP® used by the team of nurses assisting people in palliative care. Rev Eletr Enf [Internet]. 2015 [cited 2018 June 20];17(2):269-77. Available from: https://www.fen.ufg.br/revista/v17/n2/ pdf/v17n2a11-en.pdf

15. Ehnfors M, Florin J, Ehrenberg A. Applicability of the International Classification of Nursing Practice $(I C N P ®)$ in the areas of nutrition and skin care. Int J Nurs Terminol Classif. 2003;14(1):5-18. DOI: https://doi.org/10.1111/j.1744-618X.2003.tb00052.x

16. Juvé Udina ME, Gonzalez Samartino M, Matud Calvo C. Mapping the diagnosis axis of an interface terminology to the NANDA internationa taxonomy. ISRN Nurs [Internet]. 2012 [cited 2018 July 20];2012:676905. Available from: https://www.ncbi.nlm.nih.gov/pmc/articles/ PMC3399394/

17. Hardiker NR, Sermeus W, Jansen K. Challenges associated with the secondary use of nursing data. Stud Health Technol Inform. 2014;201:290-7. DOI: http://dx.doi.org/10.3233/9781614994152290 
18. Gomes DC, Oliveira LES, Cubas MR, Barra CMCM. Use of computational tools as support to the cross-mapping method between clinical terminologies. Texto Contexto Enferm. 2019; 28:e20170187. DOI: https://dx.doi.org/10.1590/1980-265X-TCE-2017-0187

19. Cubas MR. Ensuring a unified and cross-cultural nursing language system: the challenge faced by nursing terminology development. Rev Esc Enferm USP. 2015;49(4):534-5. DOI: http://dx.doi.org/10.1590/S0080-623420150000400001

20. Conselho Internacional de Enfermeiros. Classificação Internacional para a Prática de Enfermagem (CIPE () versão 2017. Porto Alegre: Artmed; 2018.

21. Tordai A, Ghazvinian A, Ossenbruggen JV, Musen MA, Noy NF. Lost in translation? Empirical analysis of mapping compositions for large ontologies [Internet]. 2010 [cited 2018 Mar 02]. Available from: http://ceur-ws.org/Vol-689/om2010_Tpaper2.pdf

22. Tosin MHS, Campos DM, Blanco L, Santana RF, Oliveira BGRB. Mapping nursing terms of Parkinson's disease. Rev Esc Enferm USP. 2015;49(3):411-8. DOI: http://dx.doi.org/10.1590/S0080-623420150000300008

23. Brammen D, Dewenter H, Heitmann KU, Thiemann V, Majeed RW, Walcher F, et al. Mapping equivalence of German Emergency Department Medical Record concepts with SNOMED CT after implementation with HL7 CDA. Stud Health Technol Inform. 2017;243:1759. DOI: 10.3233/978-1-61499-808-2-175

24. Fortune N, Hardiker NR, Strudwick G. Embedding nursing interventions into the Health Organization's International Classification of Health Interventions (ICHI). J Am Med Inform Assoc. 2017;24(4):722-8. DOI: 10.1093/jamia/ocw173

25. Bonfim D, Gaidzinski RR, Santos FM, Gonçales CS, Fugulin FMT. The identification of nursing interventions in Primary Health Care: a parameter for personnel staffing. Rev Esc Enferm USP. 2012;46(6):1462-70.DOI: http://dx.doi.org/10.1590/S0080-62342012000600025

26. Taboada M, Lalín R, Martinez D. An automated approach to mapping external terminologies to the UMLS. IEEE Trans Biomed Eng. 2009;56(6):1598-605. DOI: 10.1109/TBME.2009.2015651

27. Kopanitsa G. Mapping russian laboratory terms to LOINC. Stud Health Technol Inform. 2015;210:379-83. DOI: 10.3233/978-1-61499512-8-379

28. Kim YT, Hardiker N, Coenen A. Inter-terminology mapping of nursing problems. J Inform. 2014;49:213-20. DOI: 10.1016/j.jbi.2014.03.001

29. Aronson AR, Lang FM. An overview of MetaMap: historical perspective and recent advances. J Am Med Inform Assoc [Internet]. 2010 [cited 2018 July 20];17(3):229-36. Available from: https://www.ncbi.nlm.nih.gov/pmc/articles/PMC2995713/

30. Kim TY. Automating lexical cross-mapping of ICNP® to SNOMED CT. Inform Health Soc Care. 2014;41(1):64-77. DOI: $10.3109 / 17538157.2014 .948173$

Financial support:

Coordenação de Aperfeiçoamento de Pessoal de Nível Superior (CAPES) - Financing Code 001. 